\title{
Effect of Weather on Grain Quality Traits of Durum Wheat Grown in the Northern Plains of USA
}

\author{
Sara Moayedi, Elias M. Elias, Frank A. Manthey* \\ Cereal Science Graduate Program, Department of Plant Sciences, North Dakota State University, Fargo, ND, USA \\ Email: ^frank.manthey@ndsu.edu
}

How to cite this paper: Moayedi, S., Elias, E.M. and Manthey, F.A. (2021) Effect of Weather on Grain Quality Traits of Durum Wheat Grown in the Northern Plains of USA. American Journal of Plant Sciences, 12, 1894-1911.

https://doi.org/10.4236/ajps.2021.1212131

Received: October 29, 2021

Accepted: December 25, 2021

Published: December 28, 2021

Copyright (อ 2021 by author(s) and Scientific Research Publishing Inc. This work is licensed under the Creative Commons Attribution International License (CC BY 4.0).

http://creativecommons.org/licenses/by/4.0/

\section{(c) (i) Open Access}

\begin{abstract}
The objective of this research was to determine the effect of genotype and growing environment, particularly weather, on grain quality traits of durum wheat using nine genotypes (Alkabo, Carpio, Divide, Grenora, Joppa, Maier, Mountrail, Pierce, and Tioga) grown in four years (2012-2015) at six locations in North Dakota, USA. The results of this research indicated that grain test weight, 1000-kernel weight, protein content, kernel vitreousness, and falling number were affected more by environment than by genotype. However, genotypes within an environment differed in the magnitude of their response and this difference could be used to select genotypes in a breeding program to improve quality. For a given quality trait, the magnitude of the response reflects the stability of the trait to changes in the environment. In general, the quality of durum wheat grown in the northern plains of USA was favored by warm daytime temperature, low night temperature, and low relative humidity. Growing locations with high maximum air temperature and a high number of days with temperature $\geq 30^{\circ} \mathrm{C}$ had a positive effect on grain protein content and falling number, while a high number of days with night time temperature $\leq 13^{\circ} \mathrm{C}$ were ideal for 1000 -kernel weight. Low rainfall and low relative humidity promoted a high falling number and vitreous kernel content. The results of this study suggested that genotypes could be selected based on their overall quality and their stability across environments. Trait stability could be an important consideration when growers select genotypes for planting in their fields.
\end{abstract}

\section{Keywords}

Durum Wheat, Weather, Grain Quality 


\section{Introduction}

Test weight, 1000-kernel weight, kernel vitreousness, protein content, and falling number are important grain quality factors in both grain trading and processing in durum wheat (Triticum turgidum L. ssp. durum Desf.) [1] [2]. These factors have been associated with the final quality of pasta, which is the most common end-use product of durum wheat [3] [4].

Effects of genotype and growing environment on grain quality have been well documented [5] [6] [7] [8]. Environment includes agricultural production practices and weather conditions, both of which are known to affect grain quality [1] [9] [10] [11]. Agricultural production practices include agronomic factors, such as plant nutrient availability in the soil, seeding rate and seeding date, and pest control (diseases, insects and weeds) [4] [10] [12] [13], while weather (climatic) factors include rainfall, relative humidity, and air temperature.

Much research has been published concerning the effects of overall environment and particular agronomic practices as they relate to soil fertility and biotic stressors, such as insects, disease and weeds. The research presented in this paper focused on effects of weather factors, such as air temperature, rainfall, and relative humidity on grain quality factors. Weather factors can affect grain quality by their effect on nutrient availability and on plant physiology/biochemistry. For example, excessive rainfall during the vegetative stage can leach nitrogen and other nutrients from the soil root zone reducing their availability for uptake into the plant and formation of phytochemicals, such as protein. Reduction in protein content has been associated with low kernel vitreousness [14] [15]. Damp conditions can cause bran layer to swell which increases the kernel size but not weight. Increased size without increasing in weight results in lower kernel density and ultimately in reduced test weight. Rainfall and damp conditions during grain filling can result in loss of kernel vitreousness due to moisture absorption into the grain causing the endosperm to fracture and in an increase in preharvest sprouting. Genotypes have been shown to vary in loss of vitreousness and in preharvest sprouting due to damp conditions [15] [16]. Similarly, lack of rainfall results in low soil moisture which can affect a plant's ability to absorb nutrients from the soil and to maintain cell turgor needed for proper function. When water loss via transpiration is greater than uptake by roots wilting and closure of stomata and subsequent reduction in photosynthesis occurs.

Temperature also has been related to enzyme/metabolic activity. For example, high air temperature reduces activity of key enzymes in starch synthesis during grain filling period [10] [11] [17]. Interestingly, the impact of moderately high air temperature and reduced soil water availability has less detrimental effect on protein synthesis than on starch formation, which accounts for a rise in grain protein concentration in the grain [1] [9] [18]. Cool night time temperatures have been associated with recovery of enzyme activity. High night time temperatures do not result in recovery of enzyme activity, so activity remains low until cool night time temperature returns. Test weight and 1000-kernel weight are fa- 
vored by adequate soil moisture and cool air temperatures that favor photosynthesis and starch accumulation due to longer grain filling duration [9] [10] [11].

Breeding programs select genotypes that have traits better than existing cultivars for release to growers. With variability in weather conditions, it would be useful to also consider the stability or uniformity of quality across many environments so that grain quality would be more consistent year to year. Information is limited concerning the impact of weather factors on grain quality traits of durum wheat grown in the Northern Plains of USA. This information would be useful when selecting good quality genotypes to be released to growers [19] and in selecting genotypes to be used in a breeding program to improve the stability of grain quality traits across environments. Thus, the objective of this research was to evaluate the effects of weather factors (air temperature, rainfall and relative humidity) on grain quality traits of nine selected durum wheat genotypes grown in six locations during years (2012-2015) in North Dakota.

\section{Materials and Methods}

\subsection{Genotype and Environment Selecting a Template (Sub-Heading 2.1)}

Nine durum wheat genotypes (Alkabo [20], Carpio [21], Divide [22], Grenora [23], Joppa [24], Maier [25], Mountrail [26], Pierce [27], and Tioga [28]) were harvested from unreplicated drill strip plots $(75 \times 1.2 \mathrm{~m})$ grown at six locations in four years (2012-2015) (24 environments). Growing locations included Carrington, Dickinson, Hettinger, Langdon, Minot, and Williston, North Dakota. Weather data were obtained from the North Dakota Agricultural Weather Network (NDAWN). NDAWN weather stations are located at the ND Agricultural Research Centers where drill strips samples were grown. Weather factors were recorded daily during grain filling period (the time between anthesis and physiological maturity), and included average of maximum, minimum, and mean air temperature, total rainfall, and relative humidity. The number of days when $\mathrm{T}_{\max }$ $\geq 30^{\circ} \mathrm{C}, \mathrm{T}_{\min } \leq 13^{\circ} \mathrm{C}$, and relative humidity $\geq 80 \%$, is determined from the collected weather data.

\subsection{Chemical and Physical Tests on Grain}

Grain samples were tested for test weight, protein content, falling number, 1000-kernel weight, and vitreous kernel content. AACCI Approved Methods [29] were used to determined grain test weight (method $55-10.01$ ); protein content (method 46 - 30.01); and falling number (method 56 - 81.03). 1000 Kernel weight was determined based on counting $10 \mathrm{~g}$ of clean, sound, and unbroken kernels, and adjusting weight to 1000 kernels. Vitreous kernel content was determined utilizing a farinator, which cut 50 kernels in half. Endosperm of vitreous kernels appeared translucent, while non-vitreous kernels had opaque areas in the cross section of endosperm. For each sample of grain, the farinator test was performed twice so that a total of 100 kernels from each sample were 
examined.

\subsection{Statistical Analysis}

Least square mean, median, and range for grain quality traits were determined. Least square means of durum grain quality traits for nine durum genotypes across environments were analyzed using mixed model (type III), considering environments as a random effect, and genotype as a fixed effect. In general, mixed model is used for analysis of variance for unbalanced data and in this method, locations were considered as replications. Stepwise linear regression was applied to determine which weather data explained the greatest variation in different grain quality traits. Each of the individual quality trait was considered as a dependent variable. A significance level of $p<0.05$ was used for forward inclusion of quality traits in the regression model.

All analysis was done using SAS software version 9 (SAS Institute, Cary, NC, U.S.A). Effect of environment, genotype, and genotype $\times$ environment interaction on different quality traits in grain were determined. Intraclass correlation coefficient was calculated as the proportion of variance attributed to genotype relative to that of variation of genotype $\times$ environment interaction and error variance as described by Caffe-Treml et al. [30]. Trait stability was determined by the range in response of a given genotype across all environments.

\section{Results and Discussion}

\subsection{Estimate of Variance Components for Each Quality Trait}

Estimates of variance components and intraclass correlation coefficients for each grain quality trait are shown in Table 1. Estimates of variance components were calculated to evaluate the effect of environment, genotype, and their interaction on quality characteristics. The highest relative proportion of each variance

Table 1. Estimates of variance components and intraclass correlation coefficient from evaluation of nine durum genotypes in 24 environments for grain quality traits ${ }^{\mathrm{a}}$.

\begin{tabular}{ccccc}
\hline \multicolumn{5}{c}{ Relative proportion (\%) of variance components } \\
\hline Grain Quality traits & Genotype & Environment & Residual & $\begin{array}{c}\text { Intraclass } \\
\text { correlation }\end{array}$ \\
\hline Test weight & 3 & 96 & 1 & 0.71 \\
TKW & 8 & 91 & 1 & 0.88 \\
Protein content & 2 & 97 & 1 & 0.77 \\
Vitreous kernel content & 13 & 83 & 4 & 0.79 \\
Falling number & 2 & 98 & 0 & 0.80 \\
\hline
\end{tabular}

${ }^{a}$ Nine genotypes (Alkabo, Carpio, Divide, Grenora, Joppa, Maier, Mountrail, Pierce, and Tioga) were grown in 2012, 2013, 2014, and 2015 in six locations in North Dakota. Abbreviations: TKW, thousand kernel weight. Note: Intraclass correlation coefficient ranging from 0.5 - 0.75 is moderate; while ranging from 0.75 - 0.90 is moderately high. 
component had the greatest impact on that trait [30]. Thus, according to the results, all grain quality traits evaluated were predominantly affected by the environment. The predominant influence of environment on these quality traits has also been observed by other researchers [9] [10] [11] [31] [32]. The combination of genotype $\times$ environment interaction with experimental error was represented as residuals, which had very low proportion of variance and so had the least effect on all quality traits in grain.

Intraclass correlation coefficients could be used as a measure of broad sense heritability [30]. High intraclass correlation coefficients for all quality traits indicated that selection for these traits should be effective [30] [33]. Therefore, although environment had the biggest effect on trait response, genotypes within an environment still differed in response and this difference could be used to select genotypes in a breeding program to improve quality.

\subsection{Grain Quality Traits}

Mean, median, and range of grain quality traits for each durum wheat genotype (Alkabo, Carpio, Divide, Grenora, Joppa, Maier, Mountrail, Pierce, and Tioga) averaged over 24 environments are presented in Table 2. Similarly, the mean and range of grain quality traits for each environment averaged over nine genotypes are presented in Table 3.

\subsubsection{Test Weight}

Mean test weight values averaged over environment varied with genotypes (Table 2). Among genotypes, Alkabo had the highest mean test weight $(80.0 \mathrm{~kg} / \mathrm{hl})$,

Table 2. Descriptive statistics for durum wheat quality parameters for each genotype averaged over 24 environments ${ }^{\mathrm{a}}$.

\begin{tabular}{|c|c|c|c|c|c|c|c|c|c|c|c|c|c|c|c|}
\hline \multirow{2}{*}{ Genotype } & \multicolumn{3}{|c|}{$\begin{array}{c}\text { Test weight } \\
(\mathrm{kg} / \mathrm{hl})\end{array}$} & \multicolumn{3}{|c|}{$\begin{array}{l}1000 \text { Kernel } \\
\text { weight }(\mathrm{g})\end{array}$} & \multicolumn{3}{|c|}{$\begin{array}{c}\text { Grain protein } \\
(\%)\end{array}$} & \multicolumn{3}{|c|}{$\begin{array}{l}\text { Vitreous Kernel } \\
\text { content }(\%)\end{array}$} & \multicolumn{3}{|c|}{$\begin{array}{l}\text { Falling number } \\
\qquad(\mathrm{sec})\end{array}$} \\
\hline & Mean Mec & $\operatorname{dian} \mathrm{R}$ & lange & Mean $\mathrm{Me}$ & dian 1 & Range & Mean $\mathrm{Me}$ & $\operatorname{dian} \mathrm{R}$ & lange & Mean N & edian & Range & Mean $M$ & edian & Range \\
\hline Alkabo & $80.0 \mathrm{a}$ & 80.7 & 9.2 & $41.5 \mathrm{abc}$ & 41.3 & 19.7 & $13.9 \mathrm{cde}$ & 13.5 & 6.2 & $88 c$ & 92 & 41 & $406 \mathrm{~d}$ & 427 & 505 \\
\hline Carpio & 79.7abc & 80.3 & 7.2 & $42.2 \mathrm{a}$ & 41.8 & 22.3 & $13.9 \mathrm{cde}$ & 13.4 & 5.6 & $82 d$ & 82 & 46 & $469 a$ & 514 & 480 \\
\hline Divide & $79.5 \mathrm{abc}$ & 79.9 & 8.1 & $40.8 \mathrm{bcd}$ & 40.4 & 21.6 & $14.0 \mathrm{bcd}$ & 14 & 6.3 & $88 \mathrm{c}$ & 11 & 36 & $451 \mathrm{ab}$ & 488 & 488 \\
\hline Grenora & $78.9 \mathrm{~cd}$ & 79.5 & 10.4 & $41.7 \mathrm{ab}$ & 42 & 22.9 & $13.9 \mathrm{cde}$ & 13.7 & 6.1 & $93 \mathrm{ab}$ & 93 & 22 & $431 b c$ & 462 & 498 \\
\hline Joppa & $79.5 \mathrm{abc}$ & 80.7 & 11.3 & $40.7 \mathrm{bcd}$ & 41.2 & 22.7 & $13.6 \mathrm{e}$ & 12.9 & 6.6 & $88 \mathrm{bc}$ & 93 & 39 & $419 \mathrm{~cd}$ & 450 & 513 \\
\hline Maier & $79.5 \mathrm{abc}$ & 80.1 & 9.9 & $40.4 \mathrm{~cd}$ & 40.6 & 20.7 & $14.6 \mathrm{a}$ & 14.7 & 6.1 & $93 \mathrm{ab}$ & 95 & 30 & $403 d$ & 447 & 473 \\
\hline Mountrail & $78.6 \mathrm{~d}$ & 79.4 & 10.7 & $39.8 \mathrm{~d}$ & 39.6 & 22.7 & $14.1 \mathrm{bc}$ & 13.8 & 6.9 & $92 \mathrm{ab}$ & 97 & 45 & $425 \mathrm{~cd}$ & 447 & 481 \\
\hline Pierce & $79.9 \mathrm{ab}$ & 80.5 & 9.9 & $37.3 \mathrm{e}$ & 38.6 & 18.9 & $14.2 \mathrm{~b}$ & 13.9 & 6.2 & $95 a$ & 96 & 17 & $413 c d$ & 433 & 425 \\
\hline Tioga & $79.2 \mathrm{bcd}$ & 81 & 11.1 & $41.9 \mathrm{ab}$ & 41.8 & 23.2 & $13.8 \mathrm{de}$ & 13.4 & 6.7 & $88 c$ & 92 & 37 & $412 \mathrm{~cd}$ & 446 & 475 \\
\hline Mean & 79.5 & 80.2 & 9.8 & 40.7 & 40.8 & 21.6 & 14 & 13.7 & 6.3 & 90 & 92 & 35 & 425 & 457 & 482 \\
\hline sd & 0.5 & 0.6 & 1.4 & 1.5 & 1.1 & 1.5 & 0.3 & 0.5 & 0.4 & 4 & 4 & 10 & 22 & 28 & 25 \\
\hline
\end{tabular}

${ }^{a}$ Nine genotypes were grown in 2012, 2013, 2014, and 2015 in six locations in North Dakota. Note: For each quality trait in each column, means followed by the same letter are not significantly different at $p<0.05$; sd, standard deviation. 
Table 3. Descriptive statistics for durum wheat quality parameters in each location and year average across nine genotypes ${ }^{\text {. }}$

\begin{tabular}{|c|c|c|c|c|c|c|c|c|c|c|c|c|}
\hline \multirow{2}{*}{ Environment } & \multicolumn{2}{|c|}{$\begin{array}{c}\text { Test } \\
\text { weight } \\
(\mathrm{kg} / \mathrm{hl})\end{array}$} & \multicolumn{2}{|c|}{$\begin{array}{c}1000 \text { kernel } \\
\text { weight } \\
(\mathrm{g})\end{array}$} & \multicolumn{2}{|c|}{$\begin{array}{l}\text { Grain } \\
\text { protein } \\
(\%)\end{array}$} & \multicolumn{2}{|c|}{$\begin{array}{c}\text { Vitreous } \\
\text { Kernel content } \\
(\%)\end{array}$} & \multicolumn{2}{|c|}{$\begin{array}{l}\text { Falling } \\
\text { number } \\
(\mathrm{sec})\end{array}$} & \multicolumn{2}{|c|}{$\begin{array}{c}\text { Grain } \\
\text { filling } \\
\text { duration }\end{array}$} \\
\hline & $\begin{array}{l}\text { Mean } \\
\pm \\
\text { sd }\end{array}$ & Range & $\begin{array}{l}\text { Mean } \\
\pm \\
\text { sd }\end{array}$ & Range & $\begin{array}{l}\text { Mean } \\
\pm \\
\text { sd }\end{array}$ & Range & $\begin{array}{c}\text { Mean } \\
\pm \\
\text { sd }\end{array}$ & Range & $\begin{array}{l}\text { Mean } \\
\pm \\
\text { sd }\end{array}$ & Range & $\begin{array}{l}\text { Mean } \\
\pm \\
\text { sd }\end{array}$ & Range \\
\hline $\mathrm{L}-12$ & $76.1 \pm 1.1$ & 4.2 & $43.1 \pm 2.4$ & 6.6 & $13.7 \pm 0.4$ & 1.3 & $74 \pm 10$ & 26 & $386 \pm 25$ & 74 & $28 \pm 0.6$ & 2 \\
\hline L-13 & $81.7 \pm 0.6$ & 2.3 & $47.6 \pm 2.1$ & 6.6 & $14.0 \pm 0.4$ & 1.5 & $95 \pm 5$ & 17 & $413 \pm 26$ & 94 & $40 \pm 0.6$ & 2 \\
\hline $\mathrm{L}-14$ & $81.0 \pm 0.5$ & 2.6 & $47.4 \pm 1.6$ & 5.6 & $12.9 \pm 0.5$ & 1.9 & $81 \pm 12$ & 34 & $269 \pm 39$ & 115 & $32 \pm 1.1$ & 3 \\
\hline $\mathrm{L}-15$ & $82.1 \pm 0.5$ & 2.0 & $42.1 \pm 2.0$ & 6.3 & $13.8 \pm 0.5$ & 2.1 & $90 \pm 8$ & 29 & $481 \pm 30$ & 88 & $31 \pm 0.9$ & 3 \\
\hline M-12 & $81.9 \pm 0.9$ & 3.2 & $44.9 \pm 2.7$ & 8.6 & $14.6 \pm 0.7$ & 2.6 & $93 \pm 4$ & 15 & $437 \pm 38$ & 117 & $34 \pm 0.6$ & 2 \\
\hline M-13 & $82.3 \pm 0.2$ & 1.3 & $49.4 \pm 3.1$ & 10 & $14.8 \pm 0.4$ & 1.1 & $95 \pm 3$ & 9 & $419 \pm 48$ & 152 & $36 \pm 1.1$ & 3 \\
\hline M-14 & $75.7 \pm 2.0$ & 7.8 & $42.8 \pm 2.9$ & 8.6 & $13.0 \pm 0.4$ & 1.3 & $75 \pm 8$ & 25 & $107 \pm 34$ & 123 & $36 \pm 1.1$ & 3 \\
\hline M-15 & $81.7 \pm 0.7$ & 2.7 & $39.4 \pm 2.9$ & 9.9 & $13.6 \pm 0.5$ & 1.7 & $92 \pm 6$ & 20 & $498 \pm 39$ & 128 & $35 \pm 0.9$ & 3 \\
\hline C-12 & $75.8 \pm 0.9$ & 3.5 & $39.2 \pm 1.9$ & 5.3 & $16.8 \pm 0.4$ & 1.0 & $97 \pm 1$ & 3 & $535 \pm 63$ & 168 & $29 \pm 0.9$ & 3 \\
\hline C-13 & $82.0 \pm 0.5$ & 2.0 & $45.2 \pm 1.3$ & 4.5 & $13.3 \pm 0.3$ & 1.2 & $91 \pm 4$ & 14 & $512 \pm 29$ & 82 & $28 \pm 0.6$ & 2 \\
\hline C-14 & $79.1 \pm 0.9$ & 3.7 & $43.2 \pm 2.2$ & 6.9 & $13.0 \pm 0.9$ & 2.6 & $82 \pm 12$ & 43 & $360 \pm 39$ & 119 & $34 \pm 1.6$ & 5 \\
\hline C-15 & $77.6 \pm 1.0$ & 3.8 & $33.4 \pm 2.9$ & 9.4 & $14.9 \pm 0.4$ & 1.4 & $94 \pm 2$ & 6 & $483 \pm 46$ & 165 & $22 \pm 0.8$ & 3 \\
\hline $\mathrm{W}-12$ & $72.9 \pm 1.3$ & 5.1 & $28.8 \pm 1.9$ & 5.4 & $17.9 \pm 0.5$ & 1.5 & $99 \pm 1$ & 3 & $529 \pm 27$ & 80 & $27 \pm 3.3$ & 11 \\
\hline $\mathrm{W}-13$ & $80.0 \pm 0.5$ & 1.9 & $39.7 \pm 1.4$ & 5.0 & $13.7 \pm 0.5$ & 2.0 & $95 \pm 3$ & 10 & $472 \pm 34$ & 113 & $34 \pm 1.6$ & 5 \\
\hline $\mathrm{W}-14$ & $80.1 \pm 0.6$ & 2.7 & $36.4 \pm 2.2$ & 7.3 & $12.4 \pm 0.8$ & 2.5 & $89 \pm 9$ & 28 & $456 \pm 18$ & 62 & $26 \pm 1.7$ & 6 \\
\hline $\mathrm{W}-15$ & $80.4 \pm 0.8$ & 2.9 & $35.4 \pm 1.6$ & 5.0 & $12.9 \pm 0.2$ & 0.9 & $85 \pm 8$ & 23 & $514 \pm 21$ & 72 & $24 \pm 1.4$ & 4 \\
\hline D-12 & $77.9 \pm 0.8$ & 3.3 & $35.4 \pm 1.8$ & 5.6 & $16.2 \pm 0.3$ & 1.1 & $99 \pm 0$ & 2 & $428 \pm 17$ & 46 & $24 \pm 0.7$ & 2 \\
\hline D-13 & $81.2 \pm 0.8$ & 3.1 & $35.3 \pm 1.8$ & 6.2 & $11.7 \pm 0.3$ & 1.0 & $95 \pm 3$ & 10 & $443 \pm 18$ & 57 & $30 \pm 0.8$ & 3 \\
\hline D-14 & $76.4 \pm 1.1$ & 4.6 & $48.8 \pm 1.8$ & 6.3 & $12.9 \pm 0.6$ & 1.9 & $79 \pm 11$ & 38 & $130 \pm 31$ & 100 & $41 \pm 0.6$ & 2 \\
\hline D-15 & $77.9 \pm 0.8$ & 3.8 & $34.2 \pm 1.7$ & 6.7 & $16.8 \pm 0.4$ & 1.5 & $97 \pm 2$ & 6 & $551 \pm 23$ & 81 & $25 \pm 0.8$ & 3 \\
\hline $\mathrm{H}-12$ & $79.1 \pm 1.0$ & 3.6 & $36.1 \pm 2.3$ & 6.5 & $14.8 \pm 0.5$ & 1.4 & $100 \pm 0$ & 1 & $550 \pm 26$ & 81 & $17 \pm 1.5$ & 4 \\
\hline $\mathrm{H}-13$ & $81.4 \pm 0.6$ & 2.5 & $40.4 \pm 2.6$ & 8.4 & $13.7 \pm 0.8$ & 2.8 & $98 \pm 1$ & 3 & $490 \pm 34$ & 81 & $27 \pm 1.2$ & 4 \\
\hline $\mathrm{H}-14$ & $80.9 \pm 1.0$ & 3.6 & $47.4 \pm 1.3$ & 4.6 & $12.2 \pm 0.6$ & 1.8 & $81 \pm 10$ & 27 & $270 \pm 106$ & 293 & $33 \pm 1.3$ & 3 \\
\hline $\mathrm{H}-15$ & $81.1 \pm 0.6$ & 2.4 & $41.2 \pm 1.1$ & 3.1 & $12.4 \pm 0.9$ & 2.1 & $74 \pm 11$ & 29 & $473 \pm 36$ & 117 & $31 \pm 1.2$ & 3 \\
\hline Mean \pm sd & $79.4 \pm 2.6$ & $3.3 \pm 1.3$ & $40.7 \pm 5.5$ & $6.6 \pm 1.8$ & $14.0 \pm 1.6$ & $1.7 \pm 0.6$ & $90 \pm 8$ & $18 \pm 12$ & $425 \pm 121$ & $109 \pm 51$ & $30 \pm 6$ & $4 \pm 2$ \\
\hline
\end{tabular}

${ }^{a}$ Nine genotypes (Alkabo, Carpio, Divide, Grenora, Joppa, Maier, Mountrail, Pierce, and Tioga) were grown in 2012, 2013, 2014, and 2015 in six locations in North Dakota. Abbreviations: L, Langdon; M, Minot; C, Carrington; D, Dickinson; H, Hettinger; W, Williston; sd, standard deviation.

which was significantly higher from Grenora $(78.9 \mathrm{~kg} / \mathrm{hl})$, Mountrail $(78.6$ $\mathrm{kg} / \mathrm{hl})$, and Tioga $(79.2 \mathrm{~kg} / \mathrm{hl})$. Mountrail had the lowest mean test weight value $(78.6 \mathrm{~kg} / \mathrm{hl})$. Test weight varied with environment (Table 3$)$. All but 8 of the 24 environments resulted in mean test weight above $78.2 \mathrm{~kg} / \mathrm{hl}(60 \mathrm{lb} / \mathrm{bu})$, which is 
needed for US No. 1 grade [34]. The lowest mean test weight occurred at Williston- 12 where overall average was $72.9 \mathrm{~kg} / \mathrm{hl}$, which would be a US No. 4 grade. The overall average range of test weight for the 24 environments within a genotype was greater $(9.8 \mathrm{~kg} / \mathrm{hl}$, Table 2$)$ than the range in response over genotypes within a given environment $(3.3 \mathrm{~kg} / \mathrm{hl}$, Table 3$)$. These results supported those from Table 1, which indicated that test weight was affected more by environment than by genotype.

Range in test weight varied with genotype (Table 2). The overall range was smallest with Carpio $(7.2 \mathrm{~kg} / \mathrm{hl})$ and greatest with Joppa and Tioga (11.3 and $11.1 \mathrm{~kg} / \mathrm{hl}$, respectively). Magnitude of range is an indicator of trait stability. Thus, these results indicated that test weight was more stable (less affected by environment) with Carpio and least stable with Joppa and Tioga. Difference between mean and median values was generally twice as high for Joppa and Tioga than for the other genotypes. Both Joppa and Tioga had median values that were greater than their means. This indicated that test weight values were skewed to the left (lower values) where outliers occurred for low test weight. Thus, a few low values reduced the means more than the median values. These results indicated that environments favorable for low test weight resulted in more variability.

Correlation analysis with weather factors indicated that test weight was favored by cool air temperatures. For all genotypes, test weight increased as the number of days with temperature $\leq 13^{\circ} \mathrm{C}$ increased $(r=0.5$ to $0.76, p<0.05)$ and the daily minimum temperature decreased ( $r=-0.51$ to $-0.71, p<0.05$ ). Similarly, test weight increased as the daily maximum temperature decreased for Carpio $(r=-45, p<0.05)$, Grenora $(r=-0.42, p<0.05)$, Joppa $(r=-0.44, p<$ $0.05)$, Mountrail $(r=-0.51, p<0.05)$, and Pierce $(r=-0.48, p<0.05)$. It is assumed that cooler temperatures resulted in better grain filling, which resulted in increased kernel weight and improved packing efficiency necessary for high test weight [1] [10]. Interestingly, test weight did not correlate with grain filling duration or high relative humidity. Although for Alkabo, Carpio, and Tioga a significant and negative correlation was observed between total rainfall and test weight, it was not observed with other genotypes.

Stepwise linear regression indicated that weather factors accounted for $43 \%$ $58 \%$ of variation in test weight among genotypes (Table 4). Test weight was positively affected by number of days with temperature $\leq 13^{\circ} \mathrm{C}$ and negatively affected by total rainfall during grain filling period. Cool temperatures would favor photosynthesis and subsequent starch deposition in the grain. This would increase kernel weight and size, both of which are associated with high test weight. Rainfall near harvest could cause bran to swell resulting in increased kernel size and subsequent decline in test weight. However, rainfall during early-to mid-grain filling period would not affect bran, which probably explains why there was not a significant correlation between rainfall and test weight as the response would depend on when rain occurred [11]. 
Table 4. Stepwise linear regression for weather factors affecting grain test weight in durum wheat $(\mathrm{n}=24)$.

\begin{tabular}{|c|c|c|c|c|}
\hline Genotypes & Weather data & Effect $^{a}$ & Partial $R^{2}$ & $R^{2}$ \\
\hline \multirow{2}{*}{ Alkabo } & $\mathrm{T} \min$ & $(-)$ & 0.28 & \multirow{2}{*}{0.50} \\
\hline & Total rain & $(-)$ & 0.22 & \\
\hline \multirow{2}{*}{ Carpio } & $\#$ days temp $\leq 13^{\circ} \mathrm{C}$ & $(+)$ & 0.38 & \multirow{2}{*}{0.55} \\
\hline & Total rain & $(-)$ & 0.18 & \\
\hline \multirow{2}{*}{ Divide } & $\#$ days temp $\leq 13^{\circ} \mathrm{C}$ & $(+)$ & 0.37 & \multirow{2}{*}{0.53} \\
\hline & Total rain & $(-)$ & 0.16 & \\
\hline Grenora & $\#$ days temp $\leq 13^{\circ} \mathrm{C}$ & $(+)$ & 0.43 & 0.43 \\
\hline \multirow{2}{*}{ Joppa } & $\#$ days temp $\leq 13^{\circ} \mathrm{C}$ & $(+)$ & 0.42 & \multirow{2}{*}{0.54} \\
\hline & Total rain & $(-)$ & 0.12 & \\
\hline \multirow{2}{*}{ Maier } & $\#$ days temp $\leq 13^{\circ} \mathrm{C}$ & $(+)$ & 0.36 & \multirow{2}{*}{0.49} \\
\hline & Total rain & $(-)$ & 0.12 & \\
\hline Mountrail & $\#$ days temp $\leq 13^{\circ} \mathrm{C}$ & $(+)$ & 0.58 & 0.58 \\
\hline \multirow{2}{*}{ Pierce } & $\#$ days temp $\leq 13^{\circ} \mathrm{C}$ & $(+)$ & 0.40 & \multirow{2}{*}{0.51} \\
\hline & Total rain & $(-)$ & 0.11 & \\
\hline \multirow{2}{*}{ Tioga } & Total rain & $(-)$ & 0.34 & \multirow{2}{*}{0.58} \\
\hline & $\mathrm{T} \min$ & $(-)$ & 0.24 & \\
\hline
\end{tabular}

${ }^{a}(+)$ indicates positive effect on the grain test weight; $(-)$ indicates negative effect on the grain test weight.

\subsubsection{0-Kernel Weight}

Mean values averaged over environment for 1000-kernel weight varied with genotype (Table 2). Carpio had the highest 1000-kernel weight (42.2 g), although not significantly different from Alkabo (41.5 g), Grenora (41.7 g), or Tioga (41.9 g). Pierce had the lowest mean 1000-kernel weight (37.3 g). Pierce is known to have relatively low 1000-kernel weight [27]. The overall average range of 1000-kernel weight for the 24 environments within a genotype was greater (21.6 g, Table 2) than the range in response over genotypes within a given environment $(6.6 \mathrm{~g}, \mathrm{Ta}-$ ble 3). These results supported those from Table 1, which indicated that 1000-kernel weight was affected more by environment than by genotype.

Range in 1000-kernel weight varied with genotype (Table 2). The smallest range was found with Pierce (18.9 g), which had the lowest mean 1000-kernel weight, while had the highest range $(23.2 \mathrm{~g})$. Thus, 1000 -kernel weight was more stable (less affected by environment) for Pierce than for Tioga. Difference between mean and median values was similar for genotypes except Joppa (1.5 g) and Pierce (1.3 g). Both Joppa and Pierce median values were greater than their means. This indicated that their 1000-kernel weight values were skewed to the left (lower values) showing that their TKW were more variable in environment that favored 
low kernel weights.

1000-Kernel weight also varied with environment (Table 3). Except for Hettinger-12 and Hettinger-13, environments that had short grain filling period ( $<28$ days) produced seed with low 1000-kernel weight (Table 3). 1000-Kernel weight was lowest at Williston-12 (28.8 g), which had 27 days from anthesis to harvest. Lowest mean 1000-kernel weight at Williston-12 could be explained by exposure to more days with temperature $\geq 30^{\circ} \mathrm{C}$ and fewest days with temperature $\leq 13^{\circ} \mathrm{C}$ (data was not shown). In contrast, 1000-kernel weight was greatest at Minot-13 (49.4 g) and Dickinson-14 (48.8 g) which had 36 and 41 days from anthesis to harvest, respectively.

Correlation analysis between weather factors and 1000-kernel weight indicated that for all genotypes, 1000-kernel weight increased with number of days from anthesis to harvest ( $r=0.55$ to $0.76, p<0.05)$, number of days $\leq 13^{\circ} \mathrm{C}(r=$ 0.58 to $0.73, p<0.05$ ), and except for Maier, all genotypes had increased kernel weight with increased relative humidity $(r=0.41$ to $0.54, p<0.05)$. 1000-Kernel weight decreased with increased maximum temperature $(r=-0.54$ to $-0.71, p<$ $0.05)$, high minimum temperature $(r=-0.52$ to $-0.72, p<0.05)$, and except for Maier, number of days $\geq 30^{\circ} \mathrm{C}$ ( $r=-0.40$ to $\left.-0.57, p<0.05\right)$. Increase in 1000 -kernel weight when exposed to lower temperature is attributed to prolonged grain filling duration and more starch accumulation inside the granules [10] [11]. Negative correlation between 1000-kernel weight with maximum temperature and number of days with temperature $\geq 30^{\circ} \mathrm{C}$ supported results reported by Gooding et al. [1] and Pinheiro et al. [11]. Dias and Lidon [35] also reported that high temperature reduced grain weight which arose from its effect on grain filling rate and duration.

Stepwise linear regression showed that for all genotypes except Alkabo, grain filling duration was a significant positive factor that explained $10 \%$ to $58 \%$ of the variation in 1000-kernel weight (Table 5). Carpio, with the greatest average 1000-kernel weight ( $42.2 \mathrm{~g}$ ), was mainly affected by grain filling period as it explained $58 \%$ of the variation. Positive correlation between the 1000 -kernel weight and grain filling period also supported these results. Conversely, the lowest 1000-kernel weight was observed in Pierce. Pierce was negatively affected by a number of days $\leq 13^{\circ} \mathrm{C}$, which accounted for $46 \%$ of the variation in 1000 -kernel weight.

\subsubsection{Protein Content}

Mean values averaged over the environment for kernel protein content varied with genotype (Table 2). Maier had the highest average mean protein (14.6\%) and Joppa had the lowest average mean protein content (13.6\%). The overall mean for each genotype was greater than $13.5 \%$, which is the minimum average protein content targeted for genotypes released to durum growers as cultivars. Having a minimum of $13 \%-13.5 \%$ grain protein ensures that semolina protein content will be at least $12.5 \%$, which is necessary to make pasta that has $7 \mathrm{~g}$ protein per serving; that is standard for commercial pasta sold in the US. Not all 
Table 5. Stepwise linear regression for weather factors affecting grain 1000-kernel weight in durum wheat $(\mathrm{n}=24)$.

\begin{tabular}{ccccc}
\hline Genotypes & Weather data & Effect $^{\mathrm{a}}$ & Partial $\boldsymbol{R}^{2}$ & $\boldsymbol{R}^{2}$ \\
\hline Alkabo & \# days temp $\leq 13^{\circ} \mathrm{C}$ & $(+)$ & 0.39 & 0.39 \\
Carpio & Grain filling duration & $(+)$ & 0.58 & 0.58 \\
Divide & Grain filling duration & $(+)$ & 0.55 & 0.55 \\
Grenora & Grain filling duration & $(+)$ & 0.49 & 0.49 \\
Joppa & T max & $(-)$ & 0.45 & 0.56 \\
& Grain filling duration & $(+)$ & 0.10 & \\
Maier & T min & $(-)$ & 0.51 & 0.62 \\
& Grain filling duration & $(+)$ & 0.11 & \\
Mountrail & Grain filling duration & $(+)$ & 0.54 & 0.67 \\
& T min & $(-)$ & 0.13 & \\
Pierce & \# days temp $\leq 13^{\circ} \mathrm{C}$ & $(-)$ & 0.46 & 0.57 \\
Tioga & Grain filling duration & $(+)$ & 0.11 & \\
\hline
\end{tabular}

${ }^{a}(+)$ indicates a positive effect on the grain thousand kernel weight; $(-)$ indicates a negative effect on the grain thousand kernel weight.

growing environments were favorable for high protein content. Seven environments including Langdon-14, Williston-14, Williston-15, Dickinson-13, Dickinson-14, Hettinger-14, and Hettinger-15 had overall mean protein content below $13 \%$.

For each genotype, the range in protein content over 24 environments was greater (6.3 percentage units, Table 2$)$ than the range in response over genotypes within a given environment (1.7 percentage units, Table 3 ). These results explain why the relative proportion of variance was high for the environment (97\%) than the genotype (2\%) (Table 1).

The range in kernel protein content varied with genotype (Table 2). The overall range was smallest for Carpio (5.6 percentage units) and was greatest for Mountrail and Tioga (6.9 and 6.7 percentage units, respectively). The smaller range for Carpio compared to Mountrail and Tioga indicated that kernel protein for Carpio was less affected by environment. Thus, protein content was more stable for Carpio than for Mountrail and Tioga. Depending on genotype, mean values were greater or equal to median values. This indicated that the protein content was skewed toward higher protein values, which suggested that environments favorable for high protein content resulted in greater variability than did an unfavorable environment for low or intermediate grain protein content. Difference between mean and median values were similarly low for Divide $(0.0$ percentage units), Maier (0.1 percentage units), and Grenora (0.2 percentage units) but was high for Joppa (0.7 percentage units). 
Correlation analysis between weather factors and grain protein content indicated that the latter did not relate to grain filling duration, probably because the low protein content environments ranged from 24 (Williston-15) to 41 days (Dickinson-14) (Table 3). A significant negative correlation between grain protein content and days from anthesis to harvest occurred for Carpio $(r=-0.47, p$ $<0.05)$ and Mountrail $(r=-0.49, p<0.05)$; the other genotypes did not have a significant correlation, but they had a trend toward a negative correlation between protein content and the number of days from anthesis to harvest. Generally, a long grain filling period would result in prolonged starch accumulation, which would result in a decline in percent protein. A lack of significant negative correlation between protein content and the number of days from anthesis to harvest could be due to a delay in the harvest, which while increasing days from anthesis to harvest, it might not result in prolonged grain filling but prolongs the exposure of the grain to the environment.

Grain protein content was positively correlated with high minimum air temperature for all genotypes $(r=0.44$ to $0.67, p<0.05)$ and was positively correlated with maximum air temperature $(r=0.41$ to $0.58, p<0.05)$ and the number of days $\geq 30^{\circ} \mathrm{C}(r=0.44$ to $0.59, p<0.05)$ for all genotypes except for Divide. Except for Grenora, grain protein content was negatively correlated to the number of days $\leq 13^{\circ} \mathrm{C}(r=-0.42$ to $-0.63, p<0.05)$. While a positive correlation between protein content and maximum air temperature and minimum air temperature seems to be contradictory, high minimum air temperature is warmer than low minimum temperature. Therefore, both high maximum and minimum temperatures indicated warm day and night air temperatures, respectively, which favor protein content relative to starch content in the grain. Protein content did not correlate with moisture parameters including total rainfall, relative humidity, or days with relative humidity $80 \%$ or higher. The positive effect of high air temperatures on variation in protein content was also reported by Rharrabti et al. [9] [10]. A rise in grain protein content due to high temperature could also be attributed to shorter grain filling duration, and to a decline in the starch deposition, kernel weight, test weight, and grain yield [1] [14] [18], because starch biosynthesis is more negatively affected by high air temperatures than is protein biosynthesis [36]. Fois et al. [12] and Pinheiro et al. [11] reported similar results. Conversely, a negative correlation between days $\leq 13^{\circ} \mathrm{C}$ with grain protein could be explained by starch accumulation, which is favored by cool nights. Koga et al. [37] also reported that cool air temperature resulted in prolonged grain filling, which resulted in a decreased proportion of protein content relative to starch content, and increased grain weight and yield.

Stepwise linear regression analysis indicated that $23 \%-45 \%$ of the variation in protein content among genotypes was explained by weather data (Table 6). For Alkabo, Divide, Joppa, Maier, Mountrail, and Tioga, high minimum temperature explained the most variation in grain protein content; while with Carpio, maximum temperature, and with Pierce and Grenora, exposure of more days with temperature $\geq 30^{\circ} \mathrm{C}$ caused greatest changes in this quality trait. These 
Table 6. Stepwise linear regression for weather factors affecting grain protein content in durum wheat $(\mathrm{n}=24)$.

\begin{tabular}{ccccc}
\hline Genotypes & Weather data & Effect $^{\mathrm{a}}$ & Partial $R^{2}$ & $R^{2}$ \\
\hline Alkabo & T min & $(+)$ & 0.26 & 0.26 \\
Carpio & T max & $(+)$ & 0.34 & 0.34 \\
Divide & T min & $(+)$ & 0.26 & 0.26 \\
Grenora & \# days temp $\geq 30^{\circ} \mathrm{C}$ & $(+)$ & 0.23 & 0.23 \\
Joppa & $\mathrm{T}$ min & $(+)$ & 0.35 & 0.35 \\
Maier & $\mathrm{T}$ min & $(+)$ & 0.31 & 0.31 \\
Mountrail & $\mathrm{T}$ min & $(+)$ & 0.45 & 0.45 \\
Pierce & \# days temp $\geq 30^{\circ} \mathrm{C}$ & $(+)$ & 0.34 & 0.34 \\
Tioga & $\mathrm{T} \mathrm{min}$ & $(+)$ & 0.45 & 0.45 \\
\hline
\end{tabular}

${ }^{\mathrm{a}}(+)$ indicates positive effect on the grain protein content.

results indicated the importance of air temperature on protein content, where some genotypes were more affected by high maximum temperatures as experienced during the day and other genotypes seemed to be more affected by high minimum or night-time temperatures. The effect of minimum temperature on the variation of protein content in both Maier and Joppa (highest protein content and lowest protein content, respectively) was almost similar (Table 6), suggesting that different protein content values were due in part to other environmental factors besides the weather.

\subsubsection{Vitreous Kernel Content}

Mean values averaged over environments for grain vitreousness varied with genotype (Table 2). All genotypes met the criteria for Hard Amber Durum subclassification (>75\% vitreous kernel content [34]). In addition, Grenora (93\%), Maier (93\%), Mountrail (92\%), and Pierce (95\%) met the vitreous kernel content $(\geq 90 \%)$ criteria for Choice Milling durum, an unofficial grade used by durum millers in the US. Among genotypes, the greatest overall average vitreous kernel content (95\%) belonged to Pierce, which was not significantly different from Grenora, Maier, and Mountrail. Conversely, Carpio had the lowest average kernel vitreous content (82\%) (Table 2). In addition, vitreous kernel content varied with the environment; as reflected by durum grown at 15 of the 24 environments having vitreous kernel contents of at least $90 \%$ while average vitreous kernel content of durum grown at Langdon-12 and Hettinger-15 was 74\%.

Within a genotype, the overall average range in vitreous kernel content over the 24 environments was greater ( 35 percentage units, Table 2) than the overall average range in response over genotypes within a given environment (18 percentage units, Table 3). These results supported those presented in Table 1 where the relative proportion of variance associated with the environment $(83 \%)$ was larger than that of genotype (14\%). 
The range in vitreous kernel content varied with genotype (Table 2). Pierce had the smallest range among environments, 17 percentage units and had the highest vitreous kernel content (95\%), while Carpio had the greatest range among environments, 46 percentage units and the lowest average vitreous kernel content (82\%) (Table 2). These results suggested that vitreous kernel content was most stable with Pierce and least stable with Carpio. Mean and median values were similar for Carpio, Grenora, Maier, and Pierce. Mean values tended to be less than median values for Alkabo, Divide, Joppa, Mountrail, and Tioga, which indicated these genotypes were more variable in environments that favored low vitreous kernel content.

There were no correlations between vitreous kernel content and air temperature. In general, vitreous kernel content was negatively affected by high rainfall and high relative humidity. These results supported those reported by Rharrabti et al. [10] and by the stepwise linear regression models presented in Table 7. Weather data explained none to $52 \%$ of the variation in vitreous kernel content. Vitreous kernel content of Divide, Grenora, and Joppa were not explained by weather data, while Alkabo, Carpio, Maier, Mountrail, Pierce, and Tioga were negatively affected by damp conditions caused by either rainfall or high humidity. Sieber et al. [15] also reported a decline in vitreous kernel content of durum wheat due to exposure to humidity. Since in most genotypes, weather data accounted for $18 \%$ - $52 \%$ of variability, other factors beyond weather, such as agronomic factors, accounted for durum grown at Langdon-12 and Hettinger-15 having low kernel vitreousness.

It is assumed that differences in stability were dependent on grain protein content and the ability to maintain kernel vitreousness. All genotypes had positive correlation between kernel vitreous content and protein content $(r=0.49$ to $0.68, p<0.05)$. Pierce had the second-highest protein content. The high protein

Table 7. Stepwise linear regression for weather factors with vitreous kernel content $(\mathrm{n}=$ 24).

\begin{tabular}{ccccc}
\hline Genotypes & Weather data & Effect $^{\mathrm{a}}$ & Partial $R^{2}$ & $R^{2}$ \\
\hline Alkabo & Total rain & $(-)$ & 0.18 & 0.18 \\
Carpio & \# days $\mathrm{rh} \geq 80 \%$ & $(-)$ & 0.19 & 0.19 \\
Divide & - & - & - & - \\
Grenora & - & - & - & - \\
Joppa & - & - & - & - \\
Maier & Total rain & $(-)$ & 0.22 & 0.22 \\
Mountrail & Total rain & $(-)$ & 0.52 & 0.52 \\
Pierce & rh & $(-)$ & 0.20 & 0.20 \\
Tioga & Total rain & $(-)$ & 0.21 & 0.21 \\
\hline
\end{tabular}

${ }^{a}(-)$ indicates negative effect on the vitreous kernel content. 
content is associated with the formation of a compact protein matrix, which leads to kernel vitreousness. Carpio had the fourth-lowest protein quantity, which was not significantly different from Joppa (lowest protein content). So, the low vitreous kernel content in Carpio was presumably due to its low compact protein structure, more sensitivity of this genotype to damp conditions (more days with $\mathrm{rh} \geq 80 \%$ ), and eventually its inability to maintain its vitreousness under humid environment [15] [16] [38].

\subsubsection{Falling Number}

Mean values for falling numbers averaged over the environment varied with genotype (Table 2). Alkabo and Maier had the lowest average falling number (406 and $403 \mathrm{sec}$, respectively) and Carpio had the highest average falling number $(469 \mathrm{sec})$. The average mean for falling numbers for all genotypes were all above $400 \mathrm{sec}$. However, falling numbers varied with the environment. All environments where the number of days from anthesis to harvest was $\leq 30$, had high falling numbers $(386-551 \mathrm{sec})$. The effect of days from anthesis to harvest $>30$ on the falling number was variable ranging from 107 to $498 \mathrm{sec}$. The days to harvest for the four lowest falling number environments (Langdon-14, 269 sec; Hettinger-14, 270 sec; Minot-14, $130 \mathrm{sec}$; and Dickinson-14, $130 \mathrm{sec}$ ) were 32, 33,36 , and 41 , respectively. It was not the duration of grain fill that caused the low falling number but the exposure of the grain to damp conditions. The occurrence of low falling number values with extended days from anthesis to harvest is attributed to the increased probability and increased time of being exposed to damp conditions that are favorable for preharvest germination. Within a given genotype, the overall average range of falling number values over the 24 environments were greater (482 sec, Table 2) than the overall average range in response over genotypes within a given environment (109 sec, Table 3). These results explained why the relative proportion of variance was high for the environment (98\%) than the genotype (2\%) (Table 1).

The range in falling numbers varied with genotype (Table 2). The overall range was smallest with Pierce $(425 \mathrm{sec})$ and greatest with Joppa $(513 \mathrm{sec})$. The range as an indicator of stability across environments indicates that Pierce was more stable (less affected by environment) than was Joppa. For all genotypes, median values were greater than mean values with an average difference of $32 \mathrm{sec}$. This indicates that falling number values were skewed toward lower values and that they were more variable in environments that favored low falling numbers.

Correlation analysis between weather factors and the falling number indicated that the number of days with temperature $\geq 30^{\circ} \mathrm{C}$ increased falling number values for Alkabo $(r=0.44, p<0.05)$, Maier $(r=0.44, p<0.05)$, Mountrail $(r=$ $0.49, p<0.05)$, Pierce $(r=0.45, p<0.05)$, and Tioga $(r=0.42, p<0.05)$. Conversely for all genotypes, falling number declined with increased total rainfall $(r$ $=-0.55$ to $-0.74, p<0.05)$ and falling number declined with increased number of days with relative humidity above $80 \%$ for Alkabo $(r=-0.48, p<0.05)$, Maier 
Table 8. Stepwise linear regression for weather factors with the falling number $(n=24)$.

\begin{tabular}{|c|c|c|c|c|}
\hline Genotypes & Weather data & Effect $^{\mathrm{a}}$ & Partial $R^{2}$ & $R^{2}$ \\
\hline \multirow{2}{*}{ Alkabo } & Total rain & $(-)$ & 0.44 & \multirow{2}{*}{0.54} \\
\hline & Grain filling duration & $(-)$ & 0.11 & \\
\hline Carpio & Total rain & $(-)$ & 0.55 & 0.55 \\
\hline Divide & Total rain & $(-)$ & 0.45 & 0.45 \\
\hline \multirow{2}{*}{ Grenora } & Total rain & $(-)$ & 0.31 & \multirow{2}{*}{0.44} \\
\hline & Grain filling duration & $(-)$ & 0.13 & \\
\hline \multirow{2}{*}{ Joppa } & Total rain & $(-)$ & 0.35 & \multirow{2}{*}{0.51} \\
\hline & Grain filling duration & $(-)$ & 0.16 & \\
\hline \multirow{2}{*}{ Maier } & Total rain & $(-)$ & 0.33 & \multirow{2}{*}{0.45} \\
\hline & Grain filling duration & $(-)$ & 0.12 & \\
\hline \multirow{2}{*}{ Mountrail } & Total rain & $(-)$ & 0.20 & \multirow{2}{*}{0.64} \\
\hline & Grain filling duration & $(-)$ & 0.44 & \\
\hline \multirow[b]{2}{*}{ Pierce } & Total rain & $(-)$ & 0.17 & \multirow[b]{2}{*}{0.54} \\
\hline & Grain filling duration & $(-)$ & 0.37 & \\
\hline \multirow[b]{2}{*}{ Tioga } & Total rain & $(-)$ & 0.44 & \multirow[b]{2}{*}{0.61} \\
\hline & Grain filling duration & $(-)$ & 0.18 & \\
\hline
\end{tabular}

${ }^{a}(-)$ indicates negative effect on the falling number.

$(r=-0.49, p<0.05)$, Mountrail $(r=-0.49, p<0.05)$, Pierce $(r=-0.41, p<0.05)$, and Tioga $(r=-0.44, p<0.05)$. Thus, high falling number values are favored by high air temperature and low relative humidity and rainfall. In fact, Gooding et al. [1] reported that cool wet weather during grain filling resulted in low falling number due to increased $\alpha$-amylase activity; however, dry conditions and high temperature during grain filling positively affected falling number. Stepwise linear regression analysis using weather data indicated that for all genotypes total rain and grain filling duration had a negative effect, reduced falling number, and accounted for the greatest variation $\left(R^{2}=44 \%-64 \%\right)$ in falling number (Table 8).

\section{Conclusion}

The environment had a greater effect than did genotype on grain quality traits. Weather factors, such as air temperature, rainfall, and relative humidity during grain filling were the important factors in the variation of grain quality traits for each genotype. High air temperature and more days with temperature $\geq 30^{\circ} \mathrm{C}$ promoted high falling number and grain protein content; ideal growing locations to achieve high vitreous content were those with low rainfall and relative humidity. High 1000-kernel weight and test weight were favored by growing lo- 
cations with cool air temperature. The results of this research indicated that durum should be grown in dry environment with high temperatures during a day and low temperatures during a night. Genotype selection is important since variability in grain traits as affected by the environment differed with genotype. Therefore, genotypes could be selected by growers for planting based on their overall quality and their traits stability across many environments.

\section{Acknowledgements}

This research was funded in part by North Dakota Wheat Commission and by the USDA National Institute of Food and Agriculture, Hatch project 1016344.

\section{Conflicts of Interest}

The authors declare no conflicts of interest regarding the publication of this paper.

\section{References}

[1] Gooding, M.J., Ellis, R.H., Shewry, P.R. and Schofield, J.D. (2003) Effects of Restricted Water Availability and Increased Temperature on the Grain Filling, Drying and Quality of Winter Wheat. Journal of Cereal Science, 37, 295-309. https://doi.org/10.1006/jcrs.2002.0501

[2] Posner, E.S. and Hibbs, A.N. (2005) Wheat: The Raw Material. In: Posner, E.S. and Hibbs, A.N., Ed., Wheat Flour Milling, AACC International (Cereals \& Grains Association), St. Paul, 1-46. https://doi.org/10.1094/1891127403.001

[3] Ames, N.P., Clarke, J.M., Marchylo, B.A., Dexter, J.E. and Woods, S.M. (1999) Effect of Environment and Genotype on Durum Wheat Gluten Strength and Pasta Viscoelasticity. Cereal Chemistry, 76, 582-586. https://doi.org/10.1094/CCHEM.1999.76.4.582

[4] Uthayakumaran, S. and Wrigley, C. (2017) Wheat: Grain-Quality Characteristics and Management of Quality Requirements. In: Wrigley, C., Batey, I. and Miskelly, E., Eds., Woodhead Publishing Series in Food Science, Technology and Nutrition Woodhead Publishing, Sawston, 91-134. https://doi.org/10.1016/B978-0-08-100719-8.00005-X

[5] Spiertz, J.H.J., Hamer, R.J., Xu, H., Primo-Martin, C., Don, C. and vander Putten, P.E.L. (2006) Heat Stress in Wheat (Triticum aestivum L.): Effects on Grain Growth and Quality Traits. European Journal of Agronomy, 25, 89-95.

https://doi.org/10.1016/j.eja.2006.04.012

[6] Houshmand, S., Arzani, A. and Mirmohammadi-Maibody, S.A.M. (2014) Effects of Salinity and Drought Stress on Grain Quality of Durum Wheat. Communications in Soil Science and Plant Analysis, 45, 297-308.

https://doi.org/10.1080/00103624.2013.861911

[7] Magallanes-Lopez, A.M., Ammar, K., Morales-Dorantes, A., Gonzalez-Santoyo, H., Crossa, J. and Guzman, C. (2017) Grain Quality Traits of Commercial Durum Wheat Varieties and Their Relationships with Drought Stress and Glutenin Composition. Journal of Cereal Science, 75, 1-9. https://doi.org/10.1016/j.jcs.2017.03.005

[8] Thungo, Z., Shimelis, H., Odindo, A. and Mashilo, M. (2020) Genotype-by-Environment Effects on Grain Quality among Heat and Drought Tolerant Bread Wheat (Triticum aestivum L.) genotypes. Journal of Plant Interactions, 15, 83-92. 
https://doi.org/10.1080/17429145.2020.1748732

[9] Rharrabti, Y., Royo, C., Villegas, D., Aparicio, N. and Garcia del Moral, L.F. (2003) Durum Wheat Quality in Mediterranean Environments I. Quality Expression under Different Zones, Latitudes and Water Regimes across Spain. Field Crops Research, 80, 123-131. https://doi.org/10.1016/S0378-4290(02)00176-4

[10] Rharrabti, Y., Villegas, D., Royo, C., Martos-Nunez, V. and Garcia del Moral, L.F. (2003) Durum Wheat Quality in Mediterranean Environments II. Influence of Climatic Variables and Relationships between Quality Parameters. Field Crops Research, 80, 133-140. https://doi.org/10.1016/S0378-4290(02)00177-6

[11] Pinheiro, N., Costa, R., Almeida, A.S., Coutinho, J., Gomes, C. and Macas, B. (2013) Durum Wheat Breeding in Mediterranean Environments-Influence of Climatic Variables on Quality Traits. Journal of the Science of Food and Agriculture, 25, 962-973.

[12] Fois, S., Schlichting, L., Marchylo, B., Dexter, J., Motzo, R. and Giunta, F. (2011) Environmental Conditions Affect Semolina Quality in Durum Wheat (Triticum turgidum ssp. durum L.) Genotypes with Different Gluten Strength and Gluten Protein Composition. Journal of the Science of Food and Agriculture, 91, 2664-2673. https://doi.org/10.1002/jsfa.4509

[13] Forster, S.M., Ransom, J.K., Manthey, F.A., Rickertsen, J.R. and Mehring, G.H. (2017) Planting Date, Seeding Rate, and Cultivar Impact Agronomic Traits and Semolina of Durum Wheat. American Journal of Plant Sciences, 8, 2040-2055. https://doi.org/10.4236/ajps.2017.89137

[14] Ferreira, M.S.L., Martre, P., Mangavel, C., Girousse, C., Rosa, N.N., Samson, M.F. and Morel, M.H. (2012) Physicochemical Control of Durum Wheat Grain Filling and Glutenin Polymer Assembly Under Different Temperature Regimes. Journal of Cereal Science, 56, 58-66. https://doi.org/10.1016/j.jcs.2011.11.001

[15] Sieber, A.N., Würschum, T. and Longin, C.F.H. (2015) Vitreosity, Its Stability and Relationship to Protein Content in Durum Wheat. Journal of Cereal Science, 61, 71-77. https://doi.org/10.1016/j.jcs.2014.10.008

[16] Sandhu, K., Manthey, F.A. and Elias, E. (2009) High Relative Humidity Affects Vitreousness of Durum Wheat [Triticum turgidum L. var. durum (Desf)]. Cereal Research Communications, 37, 269-275. https://doi.org/10.1556/CRC.37.2009.2.15

[17] Ozturk, A. and Aydin, F. (2004) Effect of Water Stress at Various Growth Stages on Some Quality Characteristics of Winter Wheat. Journal of Agronomy and Crop Science, 190, 93-99. https://doi.org/10.1046/j.1439-037X.2003.00080.x

[18] Flagella, Z., Giuliani, M.M., Giuzio, L., Volpi, C. and Masci, S. (2010) Influence of Water Deficit on Durum Wheat Storage Protein Composition and Technological Quality. European Journal of Agronomy, 33, 197-207. https://doi.org/10.1016/j.eja.2010.05.006

[19] Yagdi, K. and Sozen, E. (2009) Heritability, Variance Components and Correlations of Yield and Quality Traits in Durum Wheat (Triticum Durum Desf.). Pakistan Journal of Botany, 41, 753-759.

[20] Elias, E.M. and Manthey, F.A. (2007) Registration of “Alkabo" Durum Wheat. Journal of Plant Registrations, 1, 10-11. https://doi.org/10.3198/jpr2006.05.0279crc

[21] Elias, E.M., Manthey, F.A. and AbuHammad, W.A. (2014) Registration of "Carpio" Durum Wheat. Journal of Plant Registrations, 9, 78-82. https://doi.org/10.3198/jpr2014.05.0030crc

[22] Elias, E.M. and Manthey, F.A. (2007) Registration of "Divide" Durum Wheat. Journal of Plant Registrations, 1, 7-8. https://doi.org/10.3198/jpr2006.05.0281crc 
[23] Elias, E.M. and Manthey, F.A. (2007) Registration of "Grenora” Durum Wheat. Journal of Plant Registrations, 1, 8-9. https://doi.org/10.3198/jpr2006.05.0282crc

[24] Elias, E.M. and Manthey, F.A. (2016) Registration of "Joppa” Durum Wheat. Journal of Plant Registrations, 10, 139-144. https://doi.org/10.3198/jpr2015.11.0071crc

[25] Elias, E.M. and Miller, J.D. (2000) Registration of "Maier" Durum Wheat. Crop Science, 40, 1498-1499.

[26] Elias, E.M. and Miller, J.D. (2000) Registration of "Mountrail" Durum Wheat. Crop Science, 40, 1499-1500.

[27] Elias, E.M., Manthey, F.A. and Miller, J.D. (2004) Registration of "Pierce" Durum Wheat. Crop Science, 44, 1025. https://doi.org/10.2135/cropsci2004.1025

[28] Elias, E.M. and Manthey, F.A. (2012) Registration of "Tioga” Durum Wheat. Journal of Plant Registrations, 7, 69-74. https://doi.org/10.3198/jpr2012.04.0244crc

[29] AACC International (2015) Approved Methods of Analysis (11th Ed.). Method 55-10.01. Test Weight per Bushel. Approve April 13, 1961; Method 56-81.03. Determination of Falling Number. Approved November 2, 1972; Method 46-30.01. Crude protein-Combustion Method. Approved November 8, 1995, AACCI, St. Paul.

[30] Caffe-Treml, M., Glover, K.D., Krishnan, P.G., Hareland, G.A., Bondalapati, K.D. and Stein, J. (2011) Effect of Wheat Genotype and Environment on Relationships between Dough Extensibility and Breadmaking Quality. Cereal Chemistry, 88, 201-208. https://doi.org/10.1094/CCHEM-08-10-0111

[31] Dick, J.W., Walsh, D.E. and Gilles, K.A. (1974) The Effect of Field Sprouting on the Quality of Durum Wheat. Cereal Chemistry, 51, 180-187.

[32] Biddulph, T.B., Plummer, J.A., Setter, T.L. and Mares, D.J. (2008) Seasonal Conditions Influence Dormancy and Preharvest Sprouting Tolerance of Wheat (Triticum aestivum L.) in the Field. Field Crops Research, 107, 116-128.

https://doi.org/10.1016/j.fcr.2008.01.003

[33] Eagles, H.A., Hollamby, G.J. and Eastwood, R.F. (2002) Genetic and Environmental Variation for Grain Quality Traits Routinely Evaluated in Southern Australian Wheat Breeding Programs. Australian Journal of Agricultural Research, 53, 1047-1057. https://doi.org/10.1071/AR02010

[34] USDA (United States Department of Agriculture) (2013) Grain inspection Handbook-Book II. Grading Procedures. Grain Inspection, Packers and Stockyard Administration, United States Department of Agriculture, Washington DC. https://www.ams.usda.gov/sites/default/files/media/Book2.pdf

[35] Dias, A.S. and Lidon, F.C. (2009) Evaluation of Grain Filling Rate and Duration in Bread and Durum Wheat, Under Heat Stress after Anthesis. Journal of Agronomy and Crop Science, 195, 137-147. https://doi.org/10.1111/j.1439-037X.2008.00347.x

[36] Triboi, E. and Triboi-Blondel, A.M. (2002) Productivity and Grain or Seed Composition: A New Approach to an Old Problem. European Journal of Agronomy, 16, 163-186. https://doi.org/10.1016/S1161-0301(01)00146-0

[37] Koga, S., Böcker, U., Moldestad, A., Tosi, P., Shewry, P.R., Mosleth, E.F. and Uhlen, A.K. (2015) Influence of Temperature on the Composition and Polymerization of Gluten Proteins during Grain Filling in Spring Wheat (Triticum aestivum L.). Journal of Cereal Science, 65, 1-8. https://doi.org/10.1016/j.jcs.2015.05.012

[38] Cabas-Lühmann, P.A. and Manthey, F.A. (2020) Effect of Hydration on Physical Grain Quality of Durum Wheat. Cereal Chemistry, 97, 877-887. https://doi.org/10.1002/cche.10311 